\title{
Prevalence of tick infestation in goats reared under semi-intensive system
}

\author{
Asad Ali Jariko ${ }^{1}$, Riaz Ahmed Leghari ${ }^{1}$, Javaid Ali Gadahi ${ }^{2}$, Mujeeb \\ Ur Rehman Memon ${ }^{1}$, Asad Ali Khaskheli ${ }^{3 *}$, Muhammad Qasim \\ Koondhar $^{1}$, Rashid Ali Jariko ${ }^{4}$ and Muneer Ahmed Jariko ${ }^{5}$ \\ 1. Department of Veterinary Medicine, Sindh Agriculture University, Tando Jam-Pakistan \\ 2. Veterinary Parasitology, Sindh Agriculture University, Tando Jam-Pakistan \\ 3. Department of Animal Nutrition, Sindh Agriculture University, Tando Jam-Pakistan \\ 4. Department of Animal Reproduction, Sindh Agriculture University, Tando Jam-Pakistan \\ 5. Department of Livestock Management, Sindh Agriculture University, Tando Jam-Pakistan \\ *Corresponding author's email: khaskhelias@gmail.com \\ Citation \\ Asad Ali Jariko, Riaz Ahmed Leghari, Javaid Ali Gadahi, Mujeeb Ur Rehman Memon, Asad Ali Khaskheli, \\ Muhammad Qasim Koondhar, Rashid Ali Jariko and Muneer Ahmed Jariko. Prevalence of tick infestation in \\ goats reared under semi-intensive system. Pure and Applied Biology.Vol. 9, Issue 1, pp1177-1183. \\ http://dx.doi.org/10.19045/bspab.2020.90123
}

\begin{tabular}{|c|c|c|c|}
\hline Received: 06/11/2019 & Revised: 20/01/2020 & Accepted: 27/01/2020 & Online First: 07/02/2020 \\
\hline
\end{tabular}

\section{Abstract}

Study was conducted on total of 300 goats from 10 villages of Taluka Khipro, District Sanghar for the presence of tick infestation. The prevalence of tick infestation in goats was recorded as $74.33 \%$. The highest tick infestation rate was observed in Haji Ilyas Rajar (93.33\%), and the lowest (50\%) was noticed at Karim Bux Laghari. Gender wise tick infestation prevalence of both male and female in goats was recorded as $56.25 \%$ and $82.84 \%$, respectively. The age-wise tick infestation was observed $172(80 \%)$ in adults and $51(60 \%)$ in young goats. The most common tick infestation sites were recorded ears (46.4\%) followed by tail region (28\%) and around the eyes $(9.6 \%)$. The four species of ticks infesting the goats were observed as Hyalomma anatolicum, Amblyomma variegatum, Boophilus microplus, and Rhipicephalus anguineus. While the high intensity of tick infestation was recorded of Hyalomma anatolicum (43.04\%) followed by Amblyomma variegatum (26.90\%), Boophilus microplus (16.14\%) and Rhipicephalus anguineus (13.90\%). All tick-infested goats showed clinical signs of weakness, anaemia, and anorexia. Study concludes that the Hylomma was the most prevalent species of tick infesting the goats reared under the semi-intensive system. Adult female goats were more susceptible to tick infestation compared to the young males.

Keywords: Damage; External parasites; Goat; Prevalence; Tick

\section{Introduction}

Among all the domesticated animals, goat plays a significant role in the livestock sector with the estimated population of 63.3 billion heads in Pakistan, which makes it the $3^{\text {rd }}$ major goat rearing country in the world after India and China [1]. Goats fulfill the demand of meat, milk, skin and byproducts for national and international export [2]. There are various diseases of the goat including bacterial, viral, protozoal and metabolic disorders that causes economic losses. Further, external parasites like lice, ticks and mites are also very common in goats that cause major constraint in production, morbidity and mortality with clinical signs of anemia, weight loss, retarded growth, paralysis, reduce production and intense irritation leading to skin damage that causes huge economic losses by reducing the quality and market value of skin $[3,4]$. Tick infestation in goats 
causes weakness and decreases production that has a serious economic impact on the goat farming and individual and national goat production in developing countries. It has been recommended that developing countries like Pakistan must ensure a proper tick control program [5]. The major constraint in ticks and other external parasite control is the use of chemical treatment in which ticks develop chemical resistance [6]. The misuse of drugs with wrong concentration is a leading cause of the failure of the tick control programs [7, 8].

Ticks are the part of class Arachnida, order Acari with suborder Ixodida. Ticks have been classified into three families i.e. Argasidae (soft ticks), Ixodidae (hard ticks) and the monotypic family Nuttalliellidae [9]. Hyalomma, Boophilus, Haemaphysalis and Rhipicephalus are very common tick species present in Pakistan [10]. The highest tick infestation causes the anemia to animals by sucking the host blood during their prolonged attachment of the lifecycle phase of 7-14 days, which may be long depending on tick species and host association [11]. In severe infestations, the adult and growing larvae of the ticks suck $0.5-2.0 \mathrm{ml}$ blood/day and causes morbidity and mortality [12]. Tick species that remain and has two molting periods on same host are called one-host ticks. While in two host tick species, the larvae molt to the nymphal stages on the same host but after engorging nymphs disappear from the host and molt in the nearby environment and then transferred to the new host. However, lifecycle of three host ticks depends on both the larvae and nymph that leave the host to molt in another host, as attach again to the host after each phase of molting [13]. Ticks are the main vector of Hemorrhagic fever and other protozoal diseases such as Babesiosis, Anaplasmosis, Theileriosis, and Ehrlichiosisin livestock, and further, they cause severe anemia, loss of production, weakness, and immune-suppression in the infected animals. However, animal body temperature favors their growth and survival ability with relative humidity $(85 \%)$ and temperature $\left(26-37^{\circ} \mathrm{C}\right)$. These requirements always favor the growth and reproduction of ticks [14].

Infestation of ticks is no doubt a dangerous threat to the goat farmers of the developing countries like Pakistan, where people are totally dependent on goats for their lively hood. Studies on the tick prevalence has been observed in goats worldwide $[15,16]$, but in Sindh province of Pakistan especially the Khipro district still there is need of lot of investigation on the ticks. Current study was therefore planned to identify the most prevalent species of ticks among the goats in the vicinity of Khipro district, so that, species specific control may be implemented accordingly.

\section{Materials and methods}

The present study was carried out to observe the infestation of different tick species in the goats from June to September 2017. Three hundred (300) goats were selected randomly for the collection of adult ticks (have complete morphological characteristics) from the different areas of the body of the goats from the vicinity of Ten villages of Taluka Khipro, district Sanghar. All ticks were collected without damaging their mouth parts using tissue forceps as described by [17].

Collection bottles were prepared for the collection of tick species. A small quantity of plaster of Paris was placed at the bottom of each bottle so that the moisture could be maintained in the bottles. A small hole was made on the cork of each bottle with a pincer, so that, air can be passed easily. Finally bottles were covered with airy cloth and kept into bags. All collected ticks were transported to the Department of Veterinary Medicine, Sindh Agriculture University, Tando Jam for further processing. The ticks were boiled in a solution of Potassium Hydroxide $10 \%(\mathrm{KOH})$ for fifteen minutes and temporary mounting was done by glycerin for identification of different species under an electrical binocular lens microscope. 


\section{Preparation of preservation solution}

Solution of chloroform in $10 \%$ formalin was used for further processing, mounting and identification of ticks. Formalin with chloroform was prepared by taking $10 \mathrm{ml}$ of pure formalin and dissolving into $90 \mathrm{ml}$ distilled water then chloroform was added gradually.

\section{Identification and mounting of tick species}

All collected ticks were gently shifted into test tubes having a solution of $10 \%$ Potassium Hydroxide (KOH). The solution containing ticks were boiled for periods of 15 to 20 minutes to remove the hard scutum and then allowed to cool. After cooling preserved ticks were detached from the test tubes and passed through the grades of ethanol for dehydration viz 20\% 70\%, $90 \%$ and $100 \%$. In each grade of Ethanol, ticks were kept for 2 hours before shifting them to a higher grade. All ticks were washed in running tap water and transferred in the clove oil for 24-48 hours to keep soft muscles of ticks. Ticks were prepared on a glass slide for the permanent mounts by using Canada balsam (SYN, England) as a sticking agent. Glass slides were covered with cover slip to make them permanently mounted. Ticks were identified by using a bi-ocular microscope.

\section{Tick identification}

Ticks were identified with the help of the published key [18]. Identification was based on taxonomic characters including body length, mouth parts, integument texture, length of maxillary palp, basis capula, scutum color and lateral margins, genital aperture, rings and pulvilli on legs. There were no hard-fast rule to categorize ticks as un-engorged, partially-engorged and fully engorged. However, the unengorged tick was considered as larval stage with 6 legs, partially engorged tick was recognized from partially stretched body with mouth parts fully penetrated host body and fully engorged tick depicted blood filled body.

\section{Statistical analysis}

The collected data were tabulated in Microsoft Excel and statistical analysis was performed using Statistical Package for Social Sciences (SPSS) Version 24.0. The statistical differences between groups were considered significant at $(\mathrm{p}<0.05)$.

\section{Results}

Results concerning the prevalence of tick infestation in Taluka Khipro and its surroundings are presented in the Table 1. A total 300 goats of both sexes were examined for the presence of different species of ticks from 10 villages of Taluka Khipro. The examined goats revealed 223 $(74.33 \%)$ tick infestation. The village wise study data demonstrated that the highest tick infestation rate was observed $(93.33 \%)$ in Haji Illyas Rajar, and the lowest tick infestation rate $(50 \%)$ was observed in Karim Bux Laghari. Statistically there was no significant difference between the villages of Taluka Khipro against tick infestations (Table 1).

Gender wise prevalence of tick infestation in goats at Taluka Khipro is shown in the (Table2). It is given in the table that the female although were more susceptible to tick infestation (82.84\%) compared to males $(56.25 \%)$, but statistically no significant difference was observed. Further, age wise prevalence of tick infestation in goats is given in the (Table 3 ). Table 3 shows the high rate of infestation $172(80 \%)$ was observed in adult goats followed by young goats 51 (60\%). Statistically data showed no significant difference between the age groups.

Results regarding the common predilection sites of tick infestation in goats are shown in the (Table 4). Results shows that the most common predilection sites of tick infestation on the animal body surface was observed ears $(34.4 \%)$ followed by tail region $(28 \%)$, around eyes $(19.2 \%)$, udder, thigh and testes $(14.4 \%)$, neck and chest $(2.4 \%)$, and all over the body (1.6\%).

Furthermore, the species-wise frequency of ticks in goats is depicted in the Table 5. Results reveals that among all tick species, 
the highest ticks recovery was observed Hyalomma anatolicum (43.04\%) followed by Amblyomma variegatum (26.90\%), while minimum tick species infestation was recorded of Rhipicephalus anguineus $(13.90 \%)$ infesting goats in the study area (Table5).

Table 1. Village wise prevalence of tick infestation in goats

\begin{tabular}{|c|c|c|c|c|c|c|}
\hline S No. & Name of villages & $\begin{array}{c}\text { Total no of } \\
\text { animals } \\
\text { Examined }\end{array}$ & $\begin{array}{c}\begin{array}{c}\text { No. of } \\
\text { affected } \\
\text { Animals }\end{array} \\
\end{array}$ & $\begin{array}{c}\text { Prevalence } \\
(\%)\end{array}$ & Chi sq. & $P$ value \\
\hline 1 & Haji IllyasRajar & 30 & 28 & 93.33 & \multirow{11}{*}{$4.05^{*}$} & \multirow{11}{*}{0.9078} \\
\hline 2 & Aso Dahar & 30 & 27 & 90 & & \\
\hline 3 & Jean haar & 30 & 25 & 83.33 & & \\
\hline 4 & Gul Mohd Hingorja & 30 & 24 & 80 & & \\
\hline 5 & Mir Hassan Shar & 30 & 24 & 80 & & \\
\hline 6 & Jan Mohd Mor & 30 & 22 & 73.33 & & \\
\hline 7 & Pir Bux Liskani & 30 & 21 & 70 & & \\
\hline 8 & Dodo Chaniho & 30 & 19 & 63.33 & & \\
\hline 9 & Lal Khan Khaskheli & 30 & 18 & 60 & & \\
\hline 10 & Karim Bux Laghari & 30 & 15 & 50 & & \\
\hline & Grand Total & 300 & 223 & 74.33 & & \\
\hline
\end{tabular}

Table 2. Gender wise prevalence of tick infestation in goats

\begin{tabular}{|l|c|c|c|c|c|}
\hline Sex & $\begin{array}{c}\text { No of animals } \\
\text { examined }\end{array}$ & $\begin{array}{c}\text { No of animals } \\
\text { infected }\end{array}$ & $\begin{array}{c}\text { Prevalence } \\
(\boldsymbol{\%})\end{array}$ & Chi sq. & P value \\
\hline Male & 96 & 54 & 56.25 & & \multirow{2}{*}{$3.79^{*}$} \\
\hline Female & 204 & 169 & 82.84 & 0.0516 \\
\hline
\end{tabular}

Table 3. Age wise prevalence of tick infestation in goats

\begin{tabular}{|c|c|c|c|c|c|}
\hline Age & $\begin{array}{c}\text { No. animals } \\
\text { examined }\end{array}$ & $\begin{array}{c}\text { No. animals } \\
\text { affected }\end{array}$ & Percentage & Chi sq. & P value \\
\hline Adult & 215 & 172 & 80.00 & & \multirow{2}{*}{$1.98^{*}$} \\
\hline Young & 85 & 51 & 60.00 & 0.1589 \\
\hline Total & 300 & 223 & 74.33 & \\
\hline
\end{tabular}

Table 4. Tick infestation at different body parts of goats

\begin{tabular}{|c|c|c|c|c|c|c|}
\hline $\begin{array}{c}\text { Body parts of } \\
\text { the goat }\end{array}$ & $\begin{array}{c}\text { Mild tick } \\
\text { infestation } \\
\text { (Average) }\end{array}$ & $\begin{array}{c}\text { Percent } \\
(\mathbf{\%})\end{array}$ & $\begin{array}{c}\text { Moderate tick } \\
\text { infestation } \\
\text { (Average) }\end{array}$ & $\begin{array}{c}\text { Percent } \\
(\mathbf{\%})\end{array}$ & $\begin{array}{c}\text { High tick } \\
\text { infestation } \\
\text { (Average) }\end{array}$ & $\begin{array}{c}\text { Percent } \\
(\%)\end{array}$ \\
\hline Both ears & 08 & 40 & 18 & 36 & 33 & 42.31 \\
\hline $\begin{array}{c}\text { Tail, anus and } \\
\text { vagina region }\end{array}$ & 04 & 20 & 13 & 26 & 19 & 24.36 \\
\hline Around eyes & 04 & 20 & 12 & 24 & 14 & 17.95 \\
\hline $\begin{array}{c}\text { testes, udder, } \\
\text { and thighs }\end{array}$ & 02 & 10 & 03 & 06 & 07 & 8.97 \\
\hline Neck and chest & 01 & 05 & 02 & 04 & 03 & 03.85 \\
\hline $\begin{array}{c}\text { All over the } \\
\text { body }\end{array}$ & 01 & 05 & 02 & 04 & 02 & 02.56 \\
\hline $\begin{array}{c}\text { Total no. } \\
\text { infested }\end{array}$ & $\mathbf{2 0}$ & $\mathbf{1 0 0}$ & $\mathbf{5 0}$ & $\mathbf{1 0 0}$ & $\mathbf{7 8}$ & $\mathbf{1 0 0}$ \\
\hline
\end{tabular}


Table 5. Species-wise tick frequency percentage in goats

\begin{tabular}{|c|c|c|c|c|c|c|}
\hline Tick Species & $\begin{array}{c}\text { Female } \\
\text { Goat }\end{array}$ & $\begin{array}{c}\text { Frequency } \\
(\mathbf{\%})\end{array}$ & $\begin{array}{c}\text { Male } \\
\text { Goat }\end{array}$ & $\begin{array}{c}\text { Frequency } \\
(\mathbf{\%})\end{array}$ & $\begin{array}{c}\text { Total } \\
\text { (Male + } \\
\text { Female) }\end{array}$ & $\begin{array}{c}\text { Frequency } \\
(\mathbf{\%})\end{array}$ \\
\hline Hyalomma anatolicum & 70 & 42.68 & 26 & 44.06 & 96 & 43.04 \\
\hline Amblyomma variegatum & 47 & 28.65 & 13 & 22.03 & 60 & 26.90 \\
\hline Boophilus microplus & 25 & 15.24 & 11 & 18.64 & 36 & 16.14 \\
\hline Rhipicephalus anguineus & 22 & 13.41 & 9 & 15.25 & 31 & 13.90 \\
\hline Total & 164 & 100 & 59 & 100 & 223 & 100 \\
\hline
\end{tabular}

\section{Discussion}

The present study was carried out in Khipro, district Sanghar to evaluate the presence of tick species infesting the goats. The four species of ticks were identified infesting the goats (Hyalomma anatolicum, Amblyomm avariegatum, Boophilus microplus, Rhipicephalus anguineus), which is in close agreement with [19], who reported that the ticks identified from Tando Jam and its surrounding were the same as observed in the current study. The highest prevalence of the tick infestation was recorded of Hyalomma anatolicum (43.04) and the lowest of Rhipicephalus anguineus (13.90). These results are in close agreement with the study conducted by [19], who reported that Hyalomma anatolicum was predominant tick species in goats followed by Rhiphicephalus sanguineu, the prevalence of Hyalomma anatolicum and Rhipicephalus anguineus was $42.7 \%$ (309/723) and 37.6\% (272/723), respectively while $19.6 \%$ $(142 / 723)$ of animals were infested with both the species from Layyah and Muzaffargarh (Pakistan). In contrast, the lower prevalence of Rhipicephalus anguineus difference may be due to the climate condition like a hot and humid environment of the study area. [20] reported the similar results that Hyalomma anatolicum and Rhipicephalus anguineus ticks infestation recorded in goats were 44.17 and 13.59 from Tando Jam and its surrounding (Pakistan), respectively. Further, similar results were observed by [21], who reported the tick infestation rate in goats from India during the summer season. The overall tick prevalence rate was observed $72.11 \%$. The only three tick species were identified Rhipicephalus (Boophilus) microplus Haemaphysalis spp and Hyalommaspp 47.11\%, 16.34\%, and $8.65 \%$, respectively. Our results are in close agreement with previous study.

Further, the major infestation site of the tick was observed higher in both ears $42.30 \%$ and lowest no of ticks was observed around rest of the body $2.56 \%$, these results are similar with the previous study conducted by [21]. They reported the tick infestation variation on the various body parts of the goats. The most common tick predilection sites were observed on the ears $(53.57 \%)$ followed by anus and external genitalia $(14.58 \%)$ and around eyes $(6.25 \%)$ in goats. The ticks were present on the internal ears site and the ear margin. The other reason might be that the attachment of tick was dependence on the body temperature of the animal. This could be the best reason amongst others for the presence of almost increase in the intensity of ticks in the ear. Our study was mostly conducted and completed during the summer season, so it may be a reason that most of goats showed high-intensity ticks infestation at ears.

Moreover, in the present study, the clinical findings in goat were observed such as dullness and depression in severe tickinfested animals, decreased appetite, and mucous membrane was in pale color indicating anemia, thin body condition with dry and rough body coat, hair losses at ears, weakness. The clinical findings observed were similar to the study conducted by [22] who reported direct blood losses results from heavy tick burden as well as the appearance of toxicosis in sheep. The tick 
bites can be injurious that causes severe skin damages, abscess formation at the infestation site and were the entry site for the secondary bacterial infection. Another similar type of study was conducted by [23] recorded that disorders of the blood, anemia, hypersensitivity, irritability, dermatitis, skin necrosis, low weight gains, secondary infection, focal hemorrhages and inflammation of the ear orifices. Further, [24] reported that ticks also cause retard growth and reduce the productivity of the goats in Abuja, Nigeria. So these findings were similar to previously reported.

\section{Conclusion}

Present study concludes that among all tick species the Hylomma was the most prevalent species of tick infesting the goats reared under the semi-intensive system at Khipro. Females of adult age were more susceptible to tick infestation in contrast to males of young age.

\section{Authors' contributions}

Conceived and designed the experiments: AA Jariko, RA Leghari \& AA Khaskheli, Performed the experiments: AA Jariko \& RA Jariko, Analyzed the data: M UR Memon \& MQ Koondhar, Contributed reagents/materials/analysis tools: JA Gadahi \& MA Jariko, Wrote the paper: AA Khaskheli.

\section{References}

1. Yasar A, Nazir S, Tabinda AB, Nazar M, Rasheed R \& Afzaal M (2017). Socio-economic, health and agriculture benefits of rural household biogas plants in energy scarce developing countries: A case study from Pakistan. Renewable Energy pp 411.

2. Agnihotri MK, \& Rana N (2013). Status and Prospects of Meat Production and Export Potential. Phys and Nutri-geno 4: 163-175.

3. Haque M, Singh N \&Rath S (2011). Population dynamics of ticks infesting dairy animals. Ind Vet $J$ 88: 130-140.

4. Ofukwu R \& Akwuobu C (2010). Aspects of epidemiology of ectoparasite infestation of sheep and goats in Makurdi, North Central, Nigeria. Tanzania Vet $J$ 27: 36-42.

5. Bansal GC (2005). Bovine theileriosis in India: an overview. Proc. Nat. Acad Sci Ind 75: 134-143.

6. Ghosh S, Azhahianambi P \& de la Fuente J (2006). Control of ticks of ruminants, with special emphasis on livestock farming systems in India: present and future possibilities for integrated control-a review. Experi \& Appl Acar 40: 49-66.

7. Bianchi M, Barré N \&Messad S (2003). Factors related to cattle infestation level and resistance to acaricides in Boophilus microplus tick populations in New Caledonia. Vet Para 112: 75-89.

8. Pegram RG, Wilson DD \& Hansen JW (2000). Past and present national tick control programs: why they succeed or fail. Annals of the New York Acad of Sci 916: 546-554.

9. Klompen J, Black W, Keirans J \& Jr Oliver J (1996). Evolution of ticks. Annual Rev of Ento 41: 141-161.

10. Durrani AZ \& Shakoori AR (2009). Study on ecological growth conditions of cattle Hyalomma ticks in Punjab, Pakistan. Iran J of Para 4: 19-25.

11. El Hakim AE, Shahein YE, Abouelella AM \& Selim ME (2007). Purification and characterization of two larval glycoproteins from the cattle tick, Boophilus annulatus. J of Vet Sci 8: 175-180.

12. Ram H, Yadav C, Banerjee P \& Kumar $\mathrm{V}$ (2004). Tick associated mortality in cross-bred cattle calves. Ind Vet $J$ 3: 2634-2642

13. Zajac AAC \& Gary WS (2006). Margaret veterinary Clinical Parasitology. Ames, Iowa: Blackwell Pub, pp 210.

14. Aktas M, Dumanli N \& Angin M (2004). Cattle infestation by Hyalomma ticks and prevalence of Theileria in Hyalomma species in the east of Turkey. Vet para 119: 1-8. 
15. Sarkar M, Rahman SA, Sarker BK, Anisuzzaman A, Begum N \& Mondal MMH (2010). Epidemiology and pathology of ectoparasitic infestations in black Bengal goats in Gaibandha and mymensingh districts of Bangladesh. Bang J of Vet Med 8: 4150.

16. Iqbal A, Siddique F, Mahmood MS, Shamim A, Zafar T, Rasheed I, Saleem I \& Ahmad W. 2014. Prevalence and impacts of ectoparasitic fauna infesting goats (Capra hircus) of district Toba Tek Singh, Punjab Pakistan. Global Veterinaria 12: 158-164.

17. Hannan A, Mostofa M, Hoque M, Alim M \& Saifuddin A (2003). Efficacy of Ivermectin against naturally occurring gastrointestinal nematodes and ectoparasites of sheep. Bang J Anim Sci 32: 39-45.

18. Hayes WJ \& Laws ER (1991). Handbook of pesticide toxicology. Handbook of pesticide toxicology. Academic Press pp 122.

19. Sajid MS, Iqbal $\mathrm{Z}$, Khan $\mathrm{MN} \&$ Muhammad G (2008). Point prevalence of hard ticks (Ixodids) infesting domestic ruminants of lower
Punjab, Pakistan. Int J Agri Biol 10: 349-351.

20. Shahjahan Q, Arijo AG, Bhutto MB \&Dewani P (2018). Study on microbial contaminations in tick salivary glands infesting goats. J Ani \& P Sci 2:649657.

21. Gopalakrishnan A, Dimri, Nandi U, Ajith A, Joshi Y, Jhambh VR \&Yatoo MI (2017). Prevalence Study on Tick Infestations of Goat in Lower Shivalik Region of Uttarakhand Int J Agri Biol 4: 2345-2360.

22. Constantin T, Paraschiv I, Ionita M \& Mitrea IL (2012). The efficacy of different acaricides against the hard tick Dermacentor marginatus on infested sheep. Vet Med 58:359-366.

23. Hopla CE, Durden LA \& Keirans JE (1994). Ectoparasites and classification [pathogen transmission, vector-borne diseases]. Revue Scientifique et Technique de l'oie pp 234.

24. Adang KL, Ayuba J \&Yoriyo KP (2015). Ectoparasites of Sheep (Ovisariesl.) And Goats (Capra hirus L.) In Gombe, Gombe State, Nigeria. Pak J of Bio Sci 18: 224232. 